\title{
Chemical properties of complex aluminum ions
}

Propiedades químicas de los iones complejos de aluminio

Propriedades químicas de íons complexos de alumínio

\author{
Dennis Renato Manzano Vela \\ dennis.manzano@espoch.edu.ec \\ Escuela Superior Politécnica de Chimborazo - Ecuador \\ https://orcid.org/0000-0002-7834-276X
}

\begin{abstract}
The objective of this research work was to study the synthesis of metallic salts and to analyze their properties. For this purpose, tests were carried out using basic and acid solutions. These tests allowed to identify that the reaction of aluminum in the presence of sulfuric acid is an exothermic reaction whose first stage is the formation of the tetrahydroxoaluminate (III) ion complex, a process in which a significant amount of heat is released from the system and a large amount of hydrogen gas for the oxidation of aluminum, a second stage in which sulfuric acid was added to neutralize the basicity of the solution transforming the complex into disulfate-aluminate (III), Then a third stage consisted in subjecting the solution in an ice bath to decrease the solubility of the complex and the formation of whitish crystals and finally the removal of excess crystals by washing with ethanol, these tests revealed the importance of excess sulfuric acid in the stabilization of the aluminate ion and the ease of the complex ion to bind to water molecules, thus determining important properties of the reaction as the type, orientation, solubility and the intermediates affected by the metal catalysis.
\end{abstract}

Keywords: Complex ion. Solubility. Exothermic reaction. Aluminium. Chemical properties

\section{RESUMEN}

El objetivo de este trabajo de investigación fue estudiar la síntesis de sales metálicas y analizar sus propiedades. Para ello, se realizaron ensayos utilizando soluciones básicas y de tipo ácido. Estas pruebas permitieron identificar que la reacción del aluminio en presencia de ácido sulfúrico es una reacción exotérmica cuya primera etapa es la formación del complejo ión tetrahidroxoaluminato (III) proceso en el cual se libera una cantidad de calor importante desdee el sistema y una gran cantidad de hidrógeno gaseoso para la oxidación del aluminio, una segunda etapa en la cual se adicionó ácido sulfúrico para neutralizar la basicidad de la solución transformando el complejo en disulfatoaluminato (III), posteriormente una tercera etapa que consistió en someter la solución en el baño de hielo para disminuir la solubilidad del complejo y la formación de cristales blanquecinos y por último la remoción del exceso de cristales mediante lavado con etanol, estas pruebas nos revelaron la importancia del exceso de ácido sulfúrico en la estabilización del ion aluminato y la facilidad del ion complejo para unirse a las moléculas de agua, determinando de esta manera propiedades importantes de la reacción como el tipo, la orientación, solubilidad y los elementos intermedios afectados por la catálisis metálica.

Palabras clave / Descriptores: Iones complejos. Solubilidad. Reacción exotérmica. Aluminio. Propiedades químicas

\section{RESUMO}

O objetivo deste trabalho de pesquisa foi estudar a síntese de sais metálicos e analisar suas propriedades. Para isso, foram realizados testes em soluções básicas e ácidas. Esses testes permitiram identificar que a reação do alumínio na presença de ácido sulfúrico é uma reação exotérmica cuja primeira etapa é a formação do complexo iônico tetrahidroxoaluminato (III), processo em que uma quantidade significativa de calor é liberada do sistema e uma grande quantidade de hidrogênio gasoso para a oxidação do alumínio, uma segunda etapa na qual foi adicionado ácido sulfúrico para neutralizar a basicidade da solução transformando o complexo em dissulfatealuminato (III), posteriormente uma terceira etapa que consistia em submeter a solução a o banho de gelo para diminuir a solubilidade do complexo e a formação de cristais esbranquiçados e finalmente a remoção dos cristais em excesso por lavagem com etanol, esses testes revelaram a importância do excesso de ácido sulfúrico na estabilização do íon aluminato e a facilidade do íon complexo para ligam-se às moléculas de água, determinando assim propriedades importantes reação, como tipo, orientação, solubilidade e intermediários afetados pela catálise de metal.

Palavras-chave / Descritores: Í́ons complexos. Solubilidade. Reação exotérmica. Alumínio. Propriedades químicas. 


\section{INTRODUCTION}

The elements known as metals present a great attraction not only at the Adamic level but also at the business level, since it is not only the benefits and characteristics of this type of elementsthat generate interest(Abdallah et al., 2016), apart from their electrical conductivity, malleability and ductility that are undeniably the main observations and attributes to be exploited in industrial applications( $\mathrm{Li}$ et al., 2020), but also the study of their geometries and structural properties help to understand and analyze different parameters for understanding the formation of complexes or molecules classified as complex (Paterno et al., 2020), allowing in this way, identify how metal ligands are formed within a central molecule(Legg et al., 2020)(Jiang et al., 2017)(Yang et al., 2019)

This information not only discerns the general idea of a molecular geometry for the complexes, but also shows the interpretation of the types of reactions present in the formation, as well as directs the practical evidence towards the understanding of the ligands (J. Y. Xie et al., 2017).

The fundamental objective of the experimentation was to carry out a practical determination on the properties of metals subjected to different solutions of the basic type as well as the acid type(Anjum et al., 2017), and in this way to identify what type of reactions are those that occur beyond the determination of the energy involved in the reacting system(Tian et al., 2015), and to obtain a perception on the oxidation or reduction of the elements involved since it is necessary to consider that the metal used was in its basal or pure state(Boinovich et al., 2017). Based on the above, the information obtained in the practical observations can be related to the knowledge about the complexes generated around a metal(H. Xie et al., 2016).

The main research question posed in this study is how the chemical properties of complex aluminum ions are interpreted and understood within their experimental formation and what influence these properties have on the ligands. For this reason, the revision of the current state of the art is directly related to the applications of said ions in the transmission of electons or in the formation of new materials. In this way, the reported experimental methodology can be replicated at the laboratory level in a correct way by the data presented, in addition, no conflicts of interest are reported either for the reporting of results or for the applied methodology. It is important to mention that the specifics of the study are at the laboratory level as electrochemical analysis can be applied for the parity of new unspecified properties.

\section{THEORETICAL FOUNDATION}

A Complex ion consists of a central cation surrounded by several atomic groups (molecules or ions) that are called 'ligands', and that have pairs of free electrons, so they can act as donors of these pairs, forming a covalent bond coordinated with cation centers.

While this chemical species is formed by a central metal atom, often with a positive oxidation state, which is linked by a group of neutral molecules or negative ions, by means of dative or coordinated covalent bonds. The central metal atom is called the coordination center (which is why these are said to be a type of coordination complex) while the molecules or ions that donate the electron pairs of the coordinated bonds are called ligands(Belin-Ferré, 2009).

Depending on the electrical charge of the metal center and that of the ligands, complex ions can be positive (complex cations) or negative (complex anions). Aqueous substances used in the laboratory often contain several species that interact with each other and with water in such a way that they produce two or more systems in equilibrium that react simultaneously, we will call this type of equilibrium Equilibria Simultaneous or Multiple or Conditional Equilibria, which are handled by what is known as conditional constants that are the constants that we know but 
dependent or conditioned to some species such as $\mathrm{H}^{+}(\mathrm{pH})$ or some complexing agent, precipitant or agent reducing or oxidizing(Ben Jrad et al., 2019). Sometimes the conditional potential is also handled, which is the one that it depends on one of the aforementioned species. Due to their characteristics, the atoms of metallic elements tend to lose electrons in the chemical reactions in which they participate(Chaudhry et al., 2021).

However, these positively charged metal ions, or cations, rarely exist in the free state in nature, they have such a high charge / radius ratio that they quickly interact with other ions, atoms or molecules, to acquire a structure that is themodynamically more stable. either by interacting with negatively charged ions, which translates into a reduction in the total charge of the compound; or with neutral molecules, which causes an increase in the molecular radius and a consequent decrease in the charge / radius ratio(Hemaida et al., 2008).

In these associations, the molecules that provide stability to the ion commonly act as a Lewis base, that is, they have one or more pairs of unshared electrons that can "give up" to the cation increasing its stability(Mondal \& Chattopadhyay, 2019).

This group of compounds, in which a central cation is stabilized by one or more ions or molecules that act as Lewis bases, are called complex ions, or only complexes and the group of compounds that contain them are called compounds of coordination(Ben Jrad et al., 2019).

Complex ions are formed when a metal ion, acting as Lewis acid, associates with ions or molecules that act as Lewis bases. What is formed (the complex ion) is nothing other than the corresponding adduct. This phenomenon had already been discussed in relation to the solvation of metal ions. When these are surrounded by water molecules (usually 4 or 6 ) they form complex ions. The stronger the base that binds to the metal cation, the more likely is the formation of the complex ion and, therefore, the higher its formation constant(Yuan et al., 2017).

An interesting case is the solubilization of hydroxides in a basic medium by the formation of complex ions in which the hydroxyl ion intervenes. When sodium hydroxide is added to a solution containing aluminum ions, aluminum hydroxide (insoluble) is formed. However, if sodium hydroxide is added further, the precipitate dissolves completely. A solution has formed in which complex aluminum ions are present(Mazzeo et al., 2020).

In general, the magnetic properties depend on the number of unpaired electrons that the complex possesses. When there are one or more unpaired electrons, the complex will be paramagnetic and will be attracted by magnetic fields in a degree proportional to the number of unpaired electrons. If there are no unpaired electrons, the compound will be diamagnetic and will be slightly repelled by magnetic fields. As being unpaired, the energy of the system is lower, if the energy doubling is small, the situation in which the electrons are unpaired, occupying the upper and lower d orbitals (high-spin configuration), is more favorable, while if the The splitting is large, the electrons will be paired at the lower d levels (low spin configuration). In the first case, the complex is strongly paramagnetic, while in the second it is only weakly (5 e-unpaired versus 1$)($ Chen et al., 2019).

\section{METHODOLOGICAL PROCEDURES}

\subsection{General procedure}

$0.3 \mathrm{~g}$ of powdered aluminum were weighed and $250 \mathrm{~mL}$ were placed in a glass and $5 \mathrm{~mL}$ of water was added. In ad-dition, a solution of $1.3 \mathrm{~g}$ of $\mathrm{KOH}$ in $20 \mathrm{~mL}$ of water was pre-pared and, in a hood, the solution was slowly added to the aluminum, exothermically producing the evolution of a gas. After the addition of the $\mathrm{KOH}$ solution was complete, the resulting solution was heated to boiling in order to dissolve any residual amount of the metal. If still some metal re-mains, the solution is filtered by gravity and the residue on the filter paper is washed twice with $3 \mathrm{~mL}$ of 
distilled water in each wash. The washings were placed in a glass contain-ing the filtrate slowly and while stirring, about $10 \mathrm{~mL}$ of $9 \mathrm{M}$ sulfuric acid are added to the filtrate, which will form a gelatinous precipitate that is redissolved when the solution becomes acidic, it can be It is necessary to warm the solution gently to dissolve the precipitate; if solid material remains, add $1 \mathrm{~mL}$ of sulfuric acid, and if it still does not dissolve, the solution should be filtered

The solution was cooled to room temperature and then the beaker was placed in an ice bath for 2030 minutes. The crystals were vacuum filtered, washed with a mixture of equal amounts of $96 \%$ ethanol and distilled water, and air dried.

\subsection{Materials and Equipment}

Equipment

- Balance

- $\quad$ Heating plate with stirring

Materials

- $250 \mathrm{~mL}$ beaker

- $\quad$ Specimens

- $\quad$ Kitasato flask

- $\quad$ Büchner funnel

- $\quad$ Rubber cone

- $\quad$ Glass rod

- $\quad$ Filter paper

- $\quad$ Glass funnel

- $\quad$ Spatula

- Medium

- $\quad$ Gripper

- $\quad$ Nut

- Watch glass

Reagents

- $\quad$ Aluminum powder

- $\quad$ Potassium hydroxide

- Distilled water

- $\quad$ Sulfuric acid

- $\quad$ Ice

- $\quad$ Ethanol 96\%

\section{RESULTS AND DISCUSSION}


The elemental aluminum used in the experimental determination is in a particulate solid state and is too volatile with its own shine of the metal, the reaction is exothermic in the preparation of the sulfuric acid solution (Wang et al., 2020).

When mixing the potassium hydroxide solution with the aluminum, the first complex is generated thanks to the reduction oxide generated in ion exchange, for this reason Equation 1 indicates the general reaction that the aluminum oxide reduction will take place through the addition of hydroxide potassium(Ramasamy et al., 2017).

$$
2 \mathrm{Al}_{\text {(solid) }}+2 \mathrm{KOH}_{\text {(liquid) }}+6 \mathrm{H}_{2} \mathrm{O}_{\text {(líquid) }} \rightarrow 2 \mathrm{~K}\left[\mathrm{Al}(\mathrm{OH})_{4}\right]_{\text {(liquid) }}+3 \mathrm{H}_{2 \text { (gas) }}
$$

The exothermic type reaction releases hydrogen gas and the solution that had a layer in phase dispersed and generated a bubbling as the hydrogen began to come out, an oxidation of aluminum and a reduction of hydrogen took place, it should be noted that the metal was dissolved in the water signing the first ligand of the complex, the solution must be stirred since the effervescence generated by the evolution of hydrogen and the exothermic reaction present does not allow the amount of aluminum to be consumed in its entirety in the reaction if it is not stirred (Park et al., 2020). Because the reaction is exothermic, it is necessary to mention that a very strong stirring can result in the overflow of the material's capacity since the change from liquid to gaseous state causes the molecules to be more dispersed. The presence of 2 half-phases is evidenced while the reaction takes place a whitish cloudy phase and a clear one at the end of the vessel. In addition, the complex formed is the tetrahydroxoaluminate (III) which is a complex ion since it is not stabilized in its electrical charge due to the excess of the basic solution and the polarity of the water with reference to the hydroxyl ion(Zhang et al., 2018).

In the second stage of the reaction, when sulfuric acid is added as observed in Equation 2, the semi-solid state of the solution disappears due to the excess of sulfuric acid, in addition, the concentration begins to neutralize the basicity of the solution and for this reason the complex gives rise to the following reaction:

$$
\mathrm{K}\left[\mathrm{Al}(\mathrm{OH})_{4}\right]_{\text {(liquid) }}+2 \mathrm{H}_{2} \mathrm{SO}_{4} \text { (liquid) } \rightarrow \mathrm{K} \mathrm{Al}\left(\mathrm{SO}_{4}\right)^{2} \text { (liquid) }+4 \mathrm{H}_{2} \mathrm{O} \text { (líquid) (2) }
$$

The complex formed in the aluminum becomes the potassium disulfatealuminate (III), reporting a semi-transparent solution without precipitates or solid or dispersed phases, however, when the solution is subjected to an ice bath, it is expected that the solubility of the complex will decrease and This affectation generates crystals within the molecular geometry of the same and these can precipitate and separate from the solution in the form of whitish crystals which complexed a quantity of water as indicated in Equation 3.

$$
\mathrm{K} \mathrm{Al}\left(\mathrm{SO}_{4}\right)^{2}{ }_{(\mathrm{ac})} \rightarrow \mathrm{K} \mathrm{Al}\left(\mathrm{SO}_{4}\right)^{2} .12 \mathrm{HO}
$$

Finally, washing with ethanol aims to eliminate the amount of water that is inside the ligand that can be considered as excess in the crystals formed.

\section{CONCLUSIONS}

Aluminum in its pure or base state can be oxidized under a reaction precursor as long as it is present in a sufficiently basic solution with the previous intervention of a ligand since water plays a fundamental role within solution and the complexing of the ligands. involved in the reaction.

The excess concentration of sulfuric acid presents one of the most important variables in the stabilization of the aluminum ion formed because it allows the neutralization of the ion complex and this can bind to the water molecules more easily. 
The solubility of the product or complex formed under these conditions is dependent on temperature because the reactions involved in obtaining it are of the exothermic type, this parameter helps us to understand that the energy released in the formation is in accordance with the solubility, since by decreasing the temperature of the solution the crystals can be stabilized and their molecular geometries clump together.

The medium, whether acidic or basic, in which the reaction takes place is essential because the cations that formed the crystals or complexes will move differently depending on the reaction that occurs. There are several ways to obtain aluminum crystal complexes according to the bibliography, but they all agree that aluminum generates double salts and for this purpose aluminum must be reacted since it is a metal that contains 3 valence electrons and a metal with only 1 valence electron resulting in the complexing of 12 water molecules within the complex, it was also determined that the aluminum complexing reaction by reduction oxide can take place together with other complex formation reactions without generating mixtures, thus being able to differentiate crystals of different colors in one solution. But the theoretical principle of the reaction remains the same to obtain an aluminum complex, a sulfate of a metal with only one valence electron and one with 3 valence electrons must be reacted, dissolving the mixtures in a solution and taking them to evaporation by means of a water bath again changing the energy of the reaction and the solubility of the complex thanks to the temperature

\section{REFERENCES}

Abdallah, M., Sobhi, M., \& Al-Tass, H. M. (2016). Corrosion inhibition of aluminum in hydrochloric acid by pyrazinamide derivatives. Journal of Molecular Liquids, 223, 1143-1150. https://doi.org/10.1016/j.molliq.2016.09.006

Anjum, S., Gurave, P., Badiger, M. V., Torris, A., Tiwari, N., \& Gupta, B. (2017). Design and development of trivalent aluminum ions induced self-healing polyacrylic acid novel hydrogels. Polymer, 126, 196-205. https://doi.org/10.1016/j.polymer.2017.08.045

Belin-Ferré, E. (2009). Properties and Applications of Complex Intermetallics (Vol. 2). WORLD SCIENTIFIC. https://doi.org/10.1142/7228

Ben Jrad, A., Kanso, H., Raviglione, D., Noguer, T., Inguimbert, N., \& Calas-Blanchard, C. (2019). Salen/salan metallic complexes as redox labels for electrochemical aptasensors. Chemical Communications, 55(85), 1282112824. https://doi.org/10.1039/c9cc07575e

Boinovich, L. B., Modin, E. B., Sayfutdinova, A. R., Emelyanenko, K. A., Vasiliev, A. L., \& Emelyanenko, A. M. (2017). Combination of Functional Nanoengineering and Nanosecond Laser Texturing for Design of Superhydrophobic Aluminum Alloy with Exceptional Mechanical and Chemical Properties. ACS Nano, 11(10), 10113-10123. https://doi.org/10.1021/acsnano.7b04634

Chaudhry, M. T., Akine, S., \& Maclachlan, M. J. (2021). Contemporary macrocycles for discrete polymetallic complexes: Precise control over structure and function. In Chemical Society Reviews (Vol. 50, Issue 19, pp. 10713-10732). Royal Society of Chemistry. https://doi.org/10.1039/d1cs00225b

Chen, Z., Xu, H., Gao, Y., Wang, X., \& Yang, T. (2019). Site-preference, electronic, magnetic, and half-metal properties of full-heusler sc2vge and a discussion on the uniform strain and tetragonal deformation effects. Crystals, 9(9). https://doi.org/10.3390/cryst9090445

Hemaida, H. A. E., Ali, A. E. D., \& Sadek, S. M. M. (2008). Potential anti-fouling agents: Metal complexes of 3-(2furylidene) hydrazino-5,6-diphenyl-1,2,4-triazine. Pigment and Resin Technology, 37(4), 243-249. https://doi.org/10.1108/03699420810887889

Jiang, J., Li, H., Huang, J., Li, K., Zeng, J., Yang, Y., Li, J., Wang, Y., Wang, J., \& Zhao, J. (2017). Investigation of the Reversible Intercalation/Deintercalation of Al into the Novel Li3VO4@C Microsphere Composite Cathode Material for Aluminum-Ion Batteries. ACS Applied Materials and Interfaces, 9(34), 28486-28494. https://doi.org/10.1021/acsami.7b07503

Legg, B. A., Baer, M. D., Chun, J., Schenter, G. K., Huang, S., Zhang, Y., Min, Y., Mundy, C. J., \& De Yoreo, J. J. (2020). Visualization of Aluminum Ions at the Mica Water Interface Links Hydrolysis State-to-Surface Potential and Particle Adhesion. Journal of the American Chemical Society, 142(13), 6093-6102. https://doi.org/10.1021/jacs.9b12530

Li, J., Gao, Y., Gao, Y., Chen, Z., Wang, R., \& Xu, Z. (2020). Study on aluminum removal through 5-sulfosalicylic acid targeting complexing and D290 resin adsorption. Minerals Engineering, 147, 106175. 
https://doi.org/10.1016/j.mineng.2019.106175

Mazzeo, F., Brunner, F., Prescimone, A., Constable, E. C., \& Housecroft, C. E. (2020). Intra-cation versus inter-cation $\pi$-contacts in $\left[\mathrm{Cu}\left(\mathrm{P}^{\wedge} \mathrm{P}\right)\left(\mathrm{N}^{\wedge} \mathrm{N}\right)\right][\mathrm{PF} 6]$ complexes. Crystals, $10(1)$. https://doi.org/10.3390/cryst10010001

Mondal, I., \& Chattopadhyay, S. (2019). Development of multi-metallic complexes using metal-salen complexes as building blocks. Journal of Coordination Chemistry, 72(19-21), 3183-3209. https://doi.org/10.1080/00958972.2019.1695048

Park, Y., Lee, D., Kim, J., Lee, G., \& Tak, Y. (2020). Fast charging with high capacity for aluminum rechargeable batteries using organic additive in an ionic liquid electrolyte. Physical Chemistry Chemical Physics, 22(47), 27525-27528. https://doi.org/10.1039/d0cp05050d

Paterno, D., Rock, E., Forbes, A., Iqbal, R., Mohammad, N., \& Suarez, S. (2020). Aluminum ions speciation and transport in acidic deep eutectic $\mathrm{AlCl} 3$ amide electrolytes. Journal of Molecular Liquids, 319, 114118. https://doi.org/10.1016/j.molliq.2020.114118

Ramasamy, H. V., Kaliyappan, K., Thangavel, R., Seong, W. M., Kang, K., Chen, Z., \& Lee, Y. S. (2017). Efficient Method of Designing Stable Layered Cathode Material for Sodium Ion Batteries Using Aluminum Doping. Journal of Physical Chemistry Letters, 8(20), 5021-5030. https://doi.org/10.1021/acs.jpclett.7b02012

Tian, J., Yan, X., Yang, H., \& Tian, F. (2015). A novel turn-on Schiff-base fluorescent sensor for aluminum(III) ions in living cells. RSC Advances, 5(129), 107012-107019. https://doi.org/10.1039/c5ra17557g

Wang, Y., Li, J., Gao, Y., Yang, Y., Gao, Y., \& Xu, Z. (2020). Removal of aluminum from rare-earth leaching solutions via a complexation-precipitation process. Hydrometallurgy, 191, 105220. https://doi.org/10.1016/j.hydromet.2019.105220

Xie, H., Wu, Y., Huang, J., Zeng, F., Wu, H., Xia, X., Yu, C., \& Wu, S. (2016). A ratiometric fluorescent probe for aluminum ions based-on monomer/excimer conversion and its applications to real samples. Talanta, 151, 8-13. https://doi.org/10.1016/j.talanta.2016.01.015

Xie, J. Y., Li, C. Y., Li, Y. F., Fu, Y. J., Nie, S. X., \& Tan, H. Y. (2017). A near-infrared chemosensor for determination of trivalent aluminum ions in living cells and tissues. Dyes and Pigments, 136, 817-824. https://doi.org/10.1016/j.dyepig.2016.09.046

Yang, M. H., Chen, S. C., Lin, Y. F., Lee, Y. C., Huang, M. Y., Chen, K. C., Wu, H. Y., Lin, P. C., Gozes, I., \& Tyan, Y. C. (2019). Reduction of aluminum ion neurotoxicity through a small peptide application - NAP treatment of Alzheimer's disease. Journal of Food and Drug Analysis, 27(2), 551-564. https://doi.org/10.1016/j.jfda.2018.11.009

Yuan, Y. J., Yu, Z. T., Chen, D. Q., \& Zou, Z. G. (2017). Metal-complex chromophores for solar hydrogen generation. Chemical Society Reviews, 46(3), 603-631. https://doi.org/10.1039/c6cs00436a

Zhang, Y., Liu, S., Ji, Y., Ma, J., \& Yu, H. (2018). Emerging Nonaqueous Aluminum-Ion Batteries: Challenges, Status, and Perspectives. Advanced Materials, 30(38), 1706310. https://doi.org/10.1002/adma.201706310 